\title{
Prenatal HIV Screening
}

National Cancer Institute

\section{Source}

National Cancer Institute. Prenatal HIV Screening. NCI Thesaurus. Code C92859.

Testing of a pregnant mother for antibodies to the human immunodeficiency virus (HIV)

in early pregnancy. Results permit management to reduce the chances of maternal transmission of HIV to the fetus. 